Despite these criticisms this programme had much to commend it. It dealt with a common group of disorders that often go undetected, explaining the main symptoms and the benefits of early treatment. It highlighted the problems of stigma and inadequate services, particularly as regards in-patient provisions.
Rectifying these is a major challenge for psychiatrists.

Peter Haddad, Senior Registrar, Meadowbrook, Hope Hospital, Stott Lane, Salford M6 $8 H G$

\title{
States of mind
} Milke Shooter recelves a bitter cbout the BBC's Mental
Heath Seceson

\section{Dear Dad,}

You know I am a secret addict of medical programmes - well, watching States of Mind was like an overdose. Remember when you caught me with your cigars and made me smoke one as a punishment? It put me off for years. Now, have I got a few questions for you...

1) Whoever agreed to those awful debates? Anthony Clare kicked off with one on the radio that deteriorated into the usual, sterile, nature v. nurture argument. That philosopher, Jonathan Glover, gave up trying to point out that they were all on the same side. Only Edna Conlon kept plugging away at the 'quality of life'. It seems to me that such splits are an inevitable result of studio dynamics, only interesting when the 'facilitator' is so biased, like Olivia O'Leary on The Big Picture, that she manages to drive both patient and psychiatrist into the same camp.

2) I liked Enemy Within, but was it accessible? It was a neat idea to offer the confessions of the great and good for us to identify with. But when the interviewee is as gruffly unapproachable as Ludovic Kennedy, as intelligently eloquent as Adam Faith, has the ego-strength of Imogen Stubbs or the apparently limitless recourse to help of Stephanie Cole, isn't that impossible to live up to? Incidentally, I cherish the memory of Anthony Clare and Michaela Strachan - it was difficult to work out who was charmed by whom, the piper or the snake.
3) Can you spare us the personal odysseys? Marjorie Wallace had important things to say about facilities for the seriously disturbed, among all that trendy community stuff. Yet Circles of Madness did seem like a middleclass crusade on behalf of the masses. I wasn't at all sure about taking someone back to the doorway from whence they were rescued, with full camera and crew. The curses of the drunken Scotsman, whose home this still was, seemed amply justified. And what on earth was Jo Brand up to in the bowels of a deserted mental hospital? Nothing either funny or informative.

4) Surely the trouble with 'factual drama', as BBC North called Go Back Out, is that it's just too good? The portrait of a young man raging against his own disintegration amidst the paralysis of everyone around him was superb. And was it the same actor playing the psychiatrist who had played the schizophrenic in an earlier episode of Peak Practice? What a role reversal! Or perhaps not - patients and doctors seemed equally impotent. In the circumstances, the young man's self-destruction in the 200, with its disturbing echoes of Ben Silcock, was at least an attempt to do something.

5) Yet perhaps we underestimate the input of your own, real-life dramas? As an account of the day-to-day torment of practice (not all on the patients' side), Minders was magnificent. But with images of such power, it's crucial that they are set in appropriate argument. And here, of course, is the crux of the question: editing. The whole series was depthcharged by the sight of the black schizophrenic, John, 
reduced by drugs from apparent vitality to a bloated, dribbling wreck. While Professor Burns and his team radiated sincerity, their actions had been clipped and telescoped to fit the images and the rationale had disappeared in the process. Medical Tribunal decisions became incomprehensible. What was left was a catch 22 world in which, no matter how you feel, you are 111 or well because my rules say you are. Scary stuffl It was all I could do to keep watching.

6) Talking of dispute, I rather welcome the sight of psychiatrists disagreeing with each other, constructively. In a subject as difficult as yours, total agreement would worry me. At least your differences offer me choices. But do you have to be so vitriolic about it all? It seemed to a simple layman that both The Talking Cure and Hearing Voices yearned for a synthesis in which there was room for all sorts of therapies, equally respected, and symptoms were there to be mastered not fought over as criteria of dangerousness. Instead they were reduced to such black and white antagonism (a phrase I use advisedly here) that it smacked of a stressed system looking for scapegoats.

7) Psychiatry is not psychosis; psychosis is not violence - or so you say. Did you realise how fascinated we are by the irrational, how much we need that 'otherness' to bolster our normality, and how keen the media would be to satisfy our appetite? Thus the unfortunate Lynn Battersby ("Child Killer's Trip to Shops", Sheffield Star) featured in at least two programmes. Meanwhile, where were the bits on child psychiatry, on learning disabilities, on the psychiatry of old age or substance misuse? Admittedly, Family Therapy still wends its weary way from week to week. The pace there is not so far removed from therapy itself - so slow and subtle it looks like an indulgence.

8) Forgive the metaphor (I know you're touchy about the Eastern Bloc) but this all felt like Russian dolls. On the outside, the system squirmed under the media spotlight. On the inside the patients were ushered into the multidisciplinary ward-round and relished it just as little. No wonder the issues wore the same face at each level. Are there lessons to be learnt here about suffering? It was surely unethical to chat to a man in front of camera, knowing that police and social workers were hiding outside to section him, and then to use his anger as 'evidence' of disturbance. How could he 'consent' to that bit of television later? Yet the same team, on Bite Back, objected to being misrepresented, their complaints being used as 'evidence' of a self-enclosed world.

9) States of Mind seemed like a steam-roller; 'unofficial' stuff popped up all over the place. Some of it was good - a stunning QED on Asperger's syndrome: I'm Not Stupid; Mike McShane's beautiful evocation of misunderstood adolescence: Crazy For a Kiss; the struggles of a manic-depressive parent: In the Interests of the Children; a succession of radio investigations of divorce and teenage suicide. Some was the same old mythology. The timing of Chiller looked deliberate; Morse mistook madness for Evil (the Devil's Disciple); Peak Practice was dismissive of therapy ('David doesn't need a psychiatrist. He needs a jobl'). Even that Jordache trial (Brookside) was 'a story of psychosis, sociopathic domestic violence and incestuous rape'. And life, as ever, wrote the issues in blood. How could you compete with the 'madness' of Oklahoma City and an American politician's reaction to it? 'Let's hope it's a couple of loony tunes. We know where we are with them...

10) Finally, your campaign against stigma. Was this really the media's attempt to cooperate, or was it just good 'copy'? Gillian Reynolds, a critic I've admired, millked cheap laughs on the News Quiz, using 'loony' as a reaction to political correctness. The Telegraph's Fritz Splegl, in his own hectoring way, called you a 'gauleiter' (bully) for daring to question discrimination. The good people of Sheffield (After the Asylum) were NIMBY-ing away against flats for former patients. Most depressing of all, a patient on Minders comforted himself that he wasn't like 'those schizophrenics ... all day long talking to themselves'.

Oh father, do you have a long way to gol

Your loving son, Ben.

P.S. The next time I introduce you to my friends, I was going to ask you to pretend to be someone more socially acceptable - like an arms salesman or live calf transporter. But it's a funny thing. Quite a lot of them saw the programmes and were absolutely riveted. Now they all want to meet you. And by the way, I had a cigar the other day. Wonderfull Can't think why I ever gave them up....

M. Shooter, Consultant Psychiatrist, Nevill Hall Hospital, Brecon Road, Abergavenny, Gwent NP7 7EG 